\title{
Urban floristics in southern Minas Gerais, Brazil
}

\author{
Maria Elisa Diniz Bucci '; Luciana Botezelli II; Felipe Clemente "I'; \\ João Paulo de Lima Braga Iv ; Eric Arruda Williams v
}

\begin{abstract}
The urban afforestation is an important tool for the formation of a city with an environmental quality. The present project has the aim to provide the qualitative inventory of all tree species and their respective families, in the neighborhood of Véu das Noivas, located in the west region of the municipality of Poços de Caldas, Minas Gerais. For each tree, geographic coordinates were collected and the species identified, with the help of experts, and with the material available in "Jardim Botânico de Poços de Caldas" foundation and bibliographies. Together, all species make a total of 497 individuals, once 185 in green spaces, 211 were located close to public highways and 101 were located close to the walls of some buildings. Among these trees, 44 species were found in green spaces, 54 in streets and 19 in vertical landscaping, distributed in 27 families present in green areas, 25 in streets and 14 in vertical landscaping. It was also noticed exotical species compose most part of the analyzed trees. It's important to remember that the usage of adequate species in urban afforestation is directly related to a correct urban planning.
\end{abstract}

Keywords: Urban afforestation; Floristic survey; Vertical landscaping

\footnotetext{
' Universidade Federal de Itajubá, Itajubá, Brazil. maelisadiniz@gmail.com

"Universidade Federal de Alfenas, Poços de Caldas, Brazil. luciana.botezelli@gmail.com

III Universidade de São Paulo, Butantã, Brazil. felipeclementeamb@gmail.com

IV Fundação Jardim Botânico de Poços de Caldas, Poços de Caldas, Brazil. braga.joao@gmail.com

${ }^{\vee}$ Escola Nacional de Botânica Tropical, Rio de Janeiro, Brazil. ericarrudawilliams@hotmail.com
} 


\section{INTRODUCTION}

According to Amato-Lourenço et al. (2016), the process of urbanization and population growth cause environmental problems and the vegetation may provide the enhancement of the environmental conditions, causing a thermal comfort. Still, the authors say the urban green spaces reduce the superficial flooding, control the atmospheric pollution and provide enhancements for the city inhabitants, presenting, beyond ecological functions, social and psychological functions.

The urban afforestation, when correctly planned, brings landscaping, environmental, social and patrimonial benefits for the population. However, when it's created in an inadequate way, it can cause problems to the population and the municipal public power. Among the benefits are: higher soil's permeability, control over air's humidity and temperature; interception of rainfall; shadowed areas; better water infiltration in soil; the function of an ecological corridor; protection for bodies of water and soil; preservation of the genetical diversity of the native flora; shelter for the silvester fauna; function of barrier against the wind, noises and high luminosity; reduction of air pollution; sequestration and storage of carbon; embellishment of the city; better psychological well-being and life quality (CEMIG, 2011).

In a vertical landscaping, the vegetal development starts from the structure or by the wall of the building and can be planted either into the soil or vases (BARBOSA and FONTES, 2016). Still, it's important to be careful with the plantation of vegetation close to buildings, considering its damaging aspects, such as foliage and branches or twigs which obstruct pipes, roots which deteriorate the structure once they penetrate into the foundations and the incident shadows onto the windows, prejudicing the internal heating, when in a place with cold weather.

The urban green areas are able to enhance population's quality of life and the public health (DADVAND et al., 2016; GOZALO et al., 2018). The urban green areas are composed of many elements, such as squares, urban parks, gardens etc. (AMATOLOURENÇO et al., 2016). Still according to Maricato, Colosso and Comarú (2018), two harmful urban factors are the lack of green areas and deforestation. 
The reason is substantiated by social benefits from urban afforestation with the necessity of existing an efficient urban planning in the city (BUCKERIDGE, 2015). The pursuit for a good quality of life for the inhabitants and the protection of the environment, of the local biodiversity and natural landscapes must configurate as important subjects in an efficient public management. Therefore, the urban afforestation starts to be an important tool for the urban planning not only for its socio-environmental concerns, but also for its capacity to protect the environment.

In this way, the main goal of this study is to provide a qualitative inventory of trees present in Véu das Noivas neighborhood, in Poços de Caldas/MG, checking the respective trees present in the local and their respective families and origins.

\section{MATERIAL E METHODS}

According to the city's master plan, Poços de Caldas is located in the microregion in southern Minas Gerais, lat. $21^{\circ} 50^{\prime} 20^{\prime \prime} \mathrm{S}$, long. 46 $33^{\prime} 53^{\prime \prime} \mathrm{W}$ Gr, with a altitude of 1.186 . The city has a total area of $544,42 \mathrm{~km}^{2}$, being $85,51 \mathrm{~km}^{2}$ of its urban area and $458,91 \mathrm{~km}^{2}$ of rural area (PMPC, 2006).

Véu das Noivas neighborhood is relatively small and located to the west, in the municipality of Poços de Caldas, next to the bus station and the city's shopping mall, strictly residential and for single-family people.

The gathered data of the trees was executed by visiting all streets in the neighborhood (Uberlândia, Irmão José Gregório, Ângelo Gaiga, Henrique Benedetti, Paulo de Oliveira, Raul Cury and Bruno Felisberti street, also João Ferrari avenue). Such visits approached three different categories of places: green spaces, streets and vertical landscaping.

To carry out the data gathering, a previously made worksheet was used with all data to be collected during each visit, helping for the creation of an inventory, census, of each visited place (Table 1). 
The identification of the trees' locations was made by a Global Positioning System (GPS). The number of the closest residence and each tree coordinates were also gathered (Table 1). The studies were done according to the sequence of the numbers of each house, in ascending order.

Table 1 - Aspects gathered in field of study

\begin{tabular}{cc}
\hline Tree Location & Street/Avenue name \\
\cline { 2 - 2 } & $\begin{array}{c}\text { Geographic coordinates (latitude, longitude) } \\
\text { Reference (number of the closest house) } \\
\text { Tree's Botanical } \\
\text { Identification }\end{array}$ \\
& Common name \\
& Scientific name \\
\hline
\end{tabular}

Source: The own authors

The species' identifications are done by a specialist who visits the neighborhood, a gathering of material for exsiccation, consultation in the Poços de Caldas' Botanical Garden foundation relevant books and bibliography. The scientifical and family names were checked through verifications in Flora do Brasil Online 2020 (FBO, 2018) and The Plant List (THE PLANT LIST, 2018) websites.

At the end of the activities in field, all collected data was organized separately per street in one worksheet. After that, basic statistics were taken from the data created for the analysis and interpretation of the results and the creation of maps for the location of each tree and their species most frequently found using $\operatorname{ArcGIS} \circledast$ 10.2.1, a geoprocessing software. Furthermore, adjusts were made on the maps by using CoreIDRAWß 2018. 


\section{RESULTS AND DISCUSSION}

\subsection{Vertical Landscaping}

101 trees were found in the vertical landscaping of some buildings present in the neighborhood. A certain disparity was found in the quantity of these trees among the analyzed streets, presenting a higher rate in Bruno Felisbertti Street and João Ferrari Avenue (Figure 1). It's important to highlight that in Ângelo Gaiga Street there are only planted species close to walls or in a small green space located in the end of the street.

Figure 1 - Quantity of planted trees in vertical landscaping per street in Véu das Noivas neighborhood, Poços de Caldas/MG

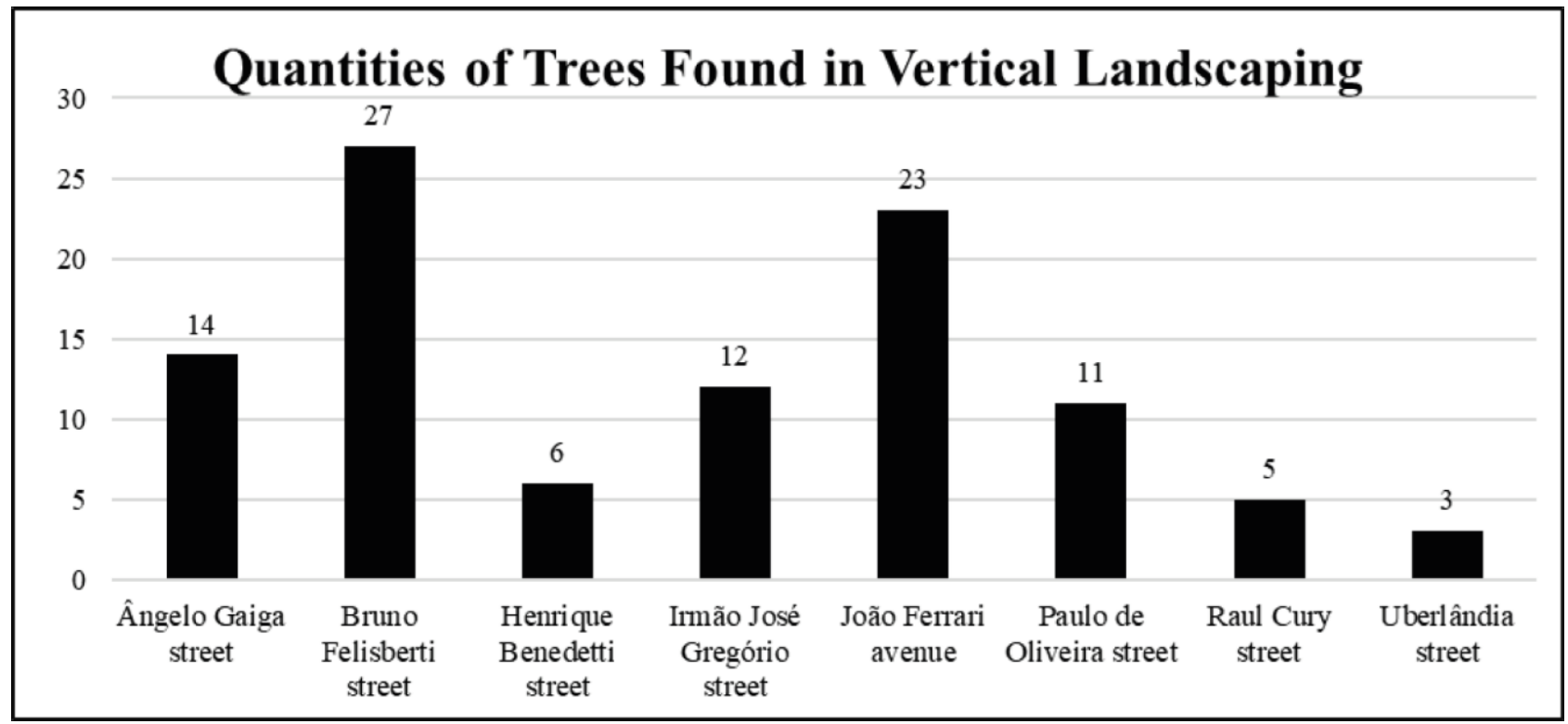

Source: the own authors

Despite the variety of found species, six of them have less than $1 \%$ of appearance rate. There's a predominance of two species: Duranta repens L. and Podocarpus macrophyllus (Thunb) D.Don (Table 2), corresponding to $57,42 \%$ of the analyzed trees, which goes over the recommended value of $10 \%$ per species (CEMIG, 2011). 
Table 2 - Family, scientific name, common name, origin and appearance rate (F) in percentages of the found species in the afforestation of green spaces in Véu das Noivas neighborhood, Poços de Caldas/MG

\begin{tabular}{|c|c|c|c|c|}
\hline Family & Scientific Name & Common Name & Origin & $F(\%)$ \\
\hline Araliaceae & $\begin{array}{c}\text { Schefflera morototoni (Aubl.) Maguire } \\
\text { et al. }\end{array}$ & morototó & Native & 1,0 \\
\hline \multirow{4}{*}{ Arecaceae } & Acanthophoenix sp. & $\begin{array}{l}\text { palmeira- } \\
\text { australiana }\end{array}$ & Exotic & 3,0 \\
\hline & $\begin{array}{c}\text { Dipsis lutescens (H.Wendl.) Beentje \& } \\
\text { J.Dransf. }\end{array}$ & areca-bambu & Exotic & 3,0 \\
\hline & Roystonea oleracea (Jacq.) O.F. Cook & $\begin{array}{l}\text { palmeira- } \\
\text { australiana }\end{array}$ & Exotic & 2,0 \\
\hline & Syagrus oleracea (Mart.) Becc. & gueroba & Native & 2,0 \\
\hline \multirow{2}{*}{ Bignoniaceae } & Jacaranda mimosifolia D. Don & jacarandá-mimoso & Exotic & 1,0 \\
\hline & Tecoma stans (L.) Juss ex. Kenth & ipê-mirim & Exotic & 2,0 \\
\hline Cupressaceae & Cupressus sempervirens L. & cipreste & Exotic & 5,0 \\
\hline Cycadaceae & Cycas circinalis L. & palmeira-sagu & Exotic & 1,0 \\
\hline Euphorbiaceae & Codiaeum variegatum L. & crotón & Exotic & 6,9 \\
\hline $\begin{array}{l}\text { Fabaceae } \\
\text { Mimosoideae }\end{array}$ & Machaerium amplum Benth. & arranha-gato & Native & 2,0 \\
\hline Moraceae & Morus nigra L. & amora-negra & Exotic & 3,0 \\
\hline \multirow{2}{*}{ Myrtaceae } & Eugenia uniflora L. & pitangueira & Native & 1,0 \\
\hline & Psidium guajava L. & goiabeira & Naturalized & 2,0 \\
\hline Pandanaceae & Pandanus sp. & pândano & Exotic & 2,0 \\
\hline Poaceae & $\begin{array}{c}\text { Phyllostachys aurea Carriére ex } \\
\text { Riviére \& C. Riviére }\end{array}$ & $\begin{array}{l}\text { taquara- } \\
\text { ornamental }\end{array}$ & Exotic & 1,0 \\
\hline Podocarpaceae & $\begin{array}{c}\text { Podocarpus macrophyllus (Thunb) } \\
\text { D.Don }\end{array}$ & podocarpos & Exotic & 28,7 \\
\hline Rutaceae & $\begin{array}{c}\text { Balfourodendron riedelianum (Engl.) } \\
\text { Engl. }\end{array}$ & guatambu & Native & 1,0 \\
\hline Verbenaceae & Duranta repens L. & pingo-de-ouro & Native & 28,7 \\
\hline - & -------------------- & indeterminate & ---------------" & 4,0 \\
\hline
\end{tabular}

Source: the own authors

The high rate of Duranta repens and Podocarpus macrophyllus can also be observed in the analysis of the found families (Figure 2), represented by the Podocarpaceae and Verbenaceae families. It was also observed that $9.9 \%$ of the found 
trees belong to the Arecaceae family, represented by trees commonly known, mostly, as palmtrees.

Figure 2 - Appearance rate in percentage about the found families in vertical landscaping in Véu das Noivas neighborhood, Poços de Caldas/MG

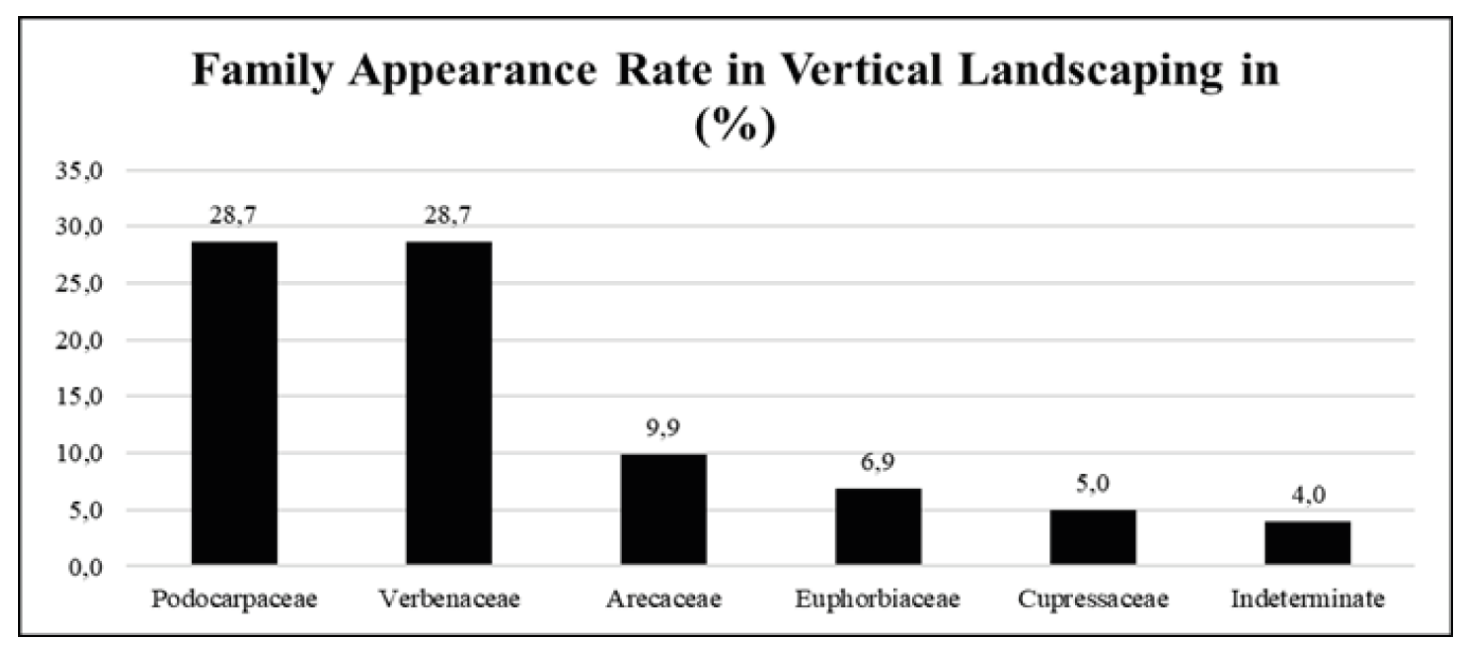

Source: the own authors

It's important to emphasize the presence of fruit trees, just like Eugenia uniflora L., Morus nigra L. and Psidium guajava L. The fruit trees are essencial for the urban fauna's maintenance being a source of food for the local animals in a way which contributes to the diversity of the species in cities, once they are able to provide fruits and food (KRAMER and KRUPEK, 2012).

In this data gathering, there is a predominance of exotic species if compared to those which are natives related to the afforestation made close to walls. More than half of the trees, $58,4 \%$ of them, are exotic, $35,6 \%$ are natives, $2,0 \%$ are naturalized and $4,0 \%$ are from unknown origin due to the impossibility of identifying because of the size of the tree (Figure 3).

It was verified that the presence of vegetation in the vertical landscape of the studied area contributed to raise the quantity of existing trees, bringing benefits for the population and for the environment. According to Barbosa and Fontes (2016), vertical landscapes are a solution to make the urban area greener once there are few areas in the cities such as destined to vegetation. 
Figure 3 - Trees' origin planted close to the wall in Véu das Noivas neighborhood, Poços de Caldas/MG

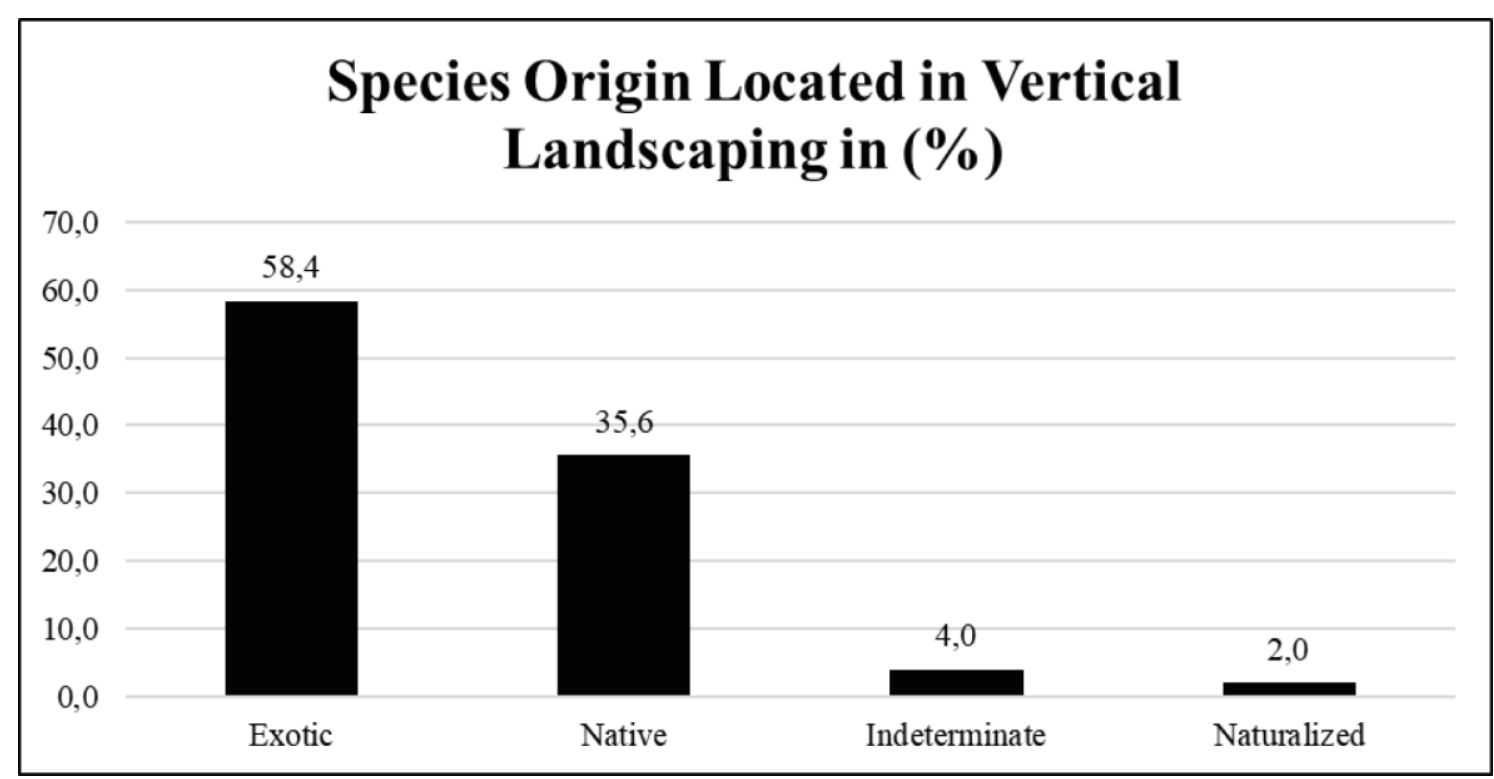

Source: the own authors

\subsection{Street Afforestation}

211 trees were found along the visited streets. However, an irregularity was noticed according to the distribution of these trees, once Raul Cury, Uberlândia, Henrique Benedetti, Irmão José Gregório, Bruno Felisbertti and Paulo de Oliveira streets have, respectfully, 4, 3, 6, 8, 16 and 22 elements and the main access to the neighborhood, João Ferrari avenue, owns 162 trees (Figure 4). It's still important to emphasize that this high number of trees found in João Ferrari avenue is due mainly to the fact of existing many trees located in their central flowerbed.

There's a big variety of tree species. Among 211 counted, there are 54 different tree species (Table 3), however, it's important to emphasize that 32 of the species own less than $1 \%$ of models.

A higher rate of the Bauhinia variegata L. species was noticed. They own a recurrent rate, mostly in the main flowerbed located in the center of João Ferrari avenue. The usage of this species results into two irregularities: its high rate and origin. According to CEMIG (2011), the maximum quantity of trees of a certain species should't go over $10 \%$, thus, the present rate $(17,54 \%)$ goes over the recommended 
limit value (Table 3). Despite being of exotic origin, their recurrent usage in the central flowerbed causes a landscaping and aesthetic effect, interesting to the neighborhood by its pink and white flowering.

Figure 4 - Quantity of planted trees per street in Véu das Noivas neighborhood, Poços de Caldas/MG

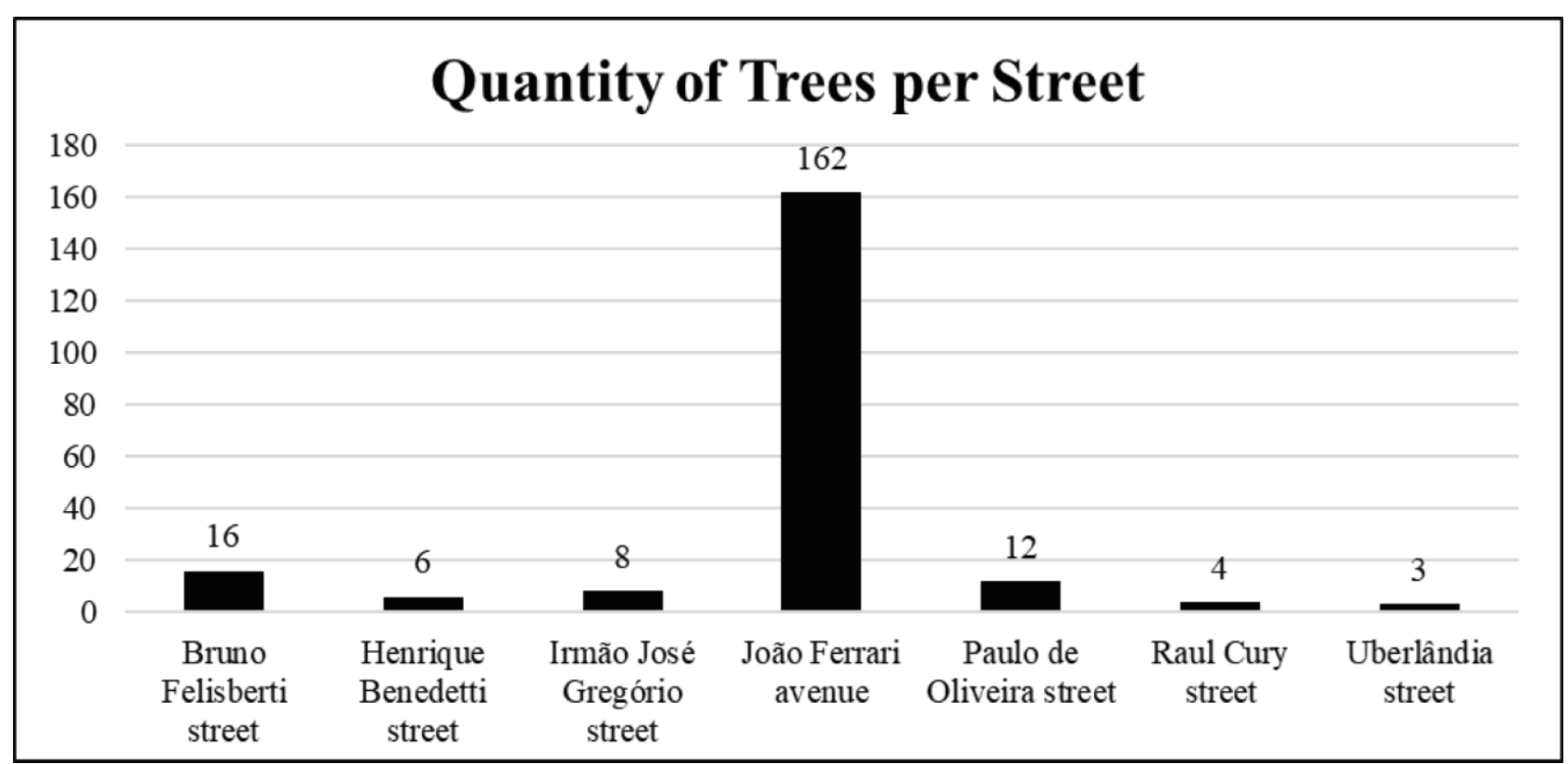

Source: the own authors.

The impossibility of identifying some species occurred, primarily, due to the gathering of data in autumn, what contributed to many trees to be without their foliage, becoming harder the identification. Even though, these trees represent 7,58\% of the data (Table 3).

Some species were the accounted fruit trees during the gathering of data: Artocarpus heterophyllus Lam., Citrus sp., Eugenia uniflora, Mangifera indica L., Morus nigra, Persea americana Mill., Psidium guajava and Punica granatum L. (Table 3). Despite producing a significative environmental gain in cities, the species which produce big fruits may cause accidents and disorder to the population (CEMIG, 2011).

During the data gathering in the streets, two invading species were found: Leucaena leucocephala (Lam.) de Wit and Pittosporum undulatum Vent. (Table 3). The species Leucaena leucocephala is exotic, can survive in many different places and, it owns a favored spreading in varied environments (SILVA et al., 2017). 
Table 3 - Family, scientific name, common name, origin and rate of appearance (F) in percentage of the found species in the afforestation of the streets in Véu das Noivas neighborhood, in Poços de Caldas/MG

\begin{tabular}{|c|c|c|c|c|}
\hline Family & Scientific Name & Common Name & Origin & $F(\%)$ \\
\hline & Mangifera indica $\mathrm{L}$. & mangueira & Exotic & 6,2 \\
\hline \multirow[t]{4}{*}{ Anacardiaceae } & Schinus molle L. & aroeira-salsa & Native & 1,0 \\
\hline & Schinus terebinthifolia Raddi & aroeira-pimenteira & Native & 3,3 \\
\hline & Beaucarnea recurvata Lem. & nolina & Exotic & 0,5 \\
\hline & Caryota mitis Lour. & palmeira rabo-de-peixe & Exotic & 0,5 \\
\hline \multirow[t]{7}{*}{ Arecaceae } & $\begin{array}{c}\text { Phoenix roebelenii (Carl } \\
\text { Roebelen) }\end{array}$ & fênix & Exotic & 0,5 \\
\hline & $\begin{array}{c}\text { Roystonea oleracea (Jacq.) O.F. } \\
\text { Cook }\end{array}$ & palmeira-australiana & Exotic & 1,9 \\
\hline & Syagrus oleracea (Mart.) Becc. & gueroba & Native & 0,5 \\
\hline & $\begin{array}{c}\text { Cybistax antisyphilitica (Mart.) } \\
\text { Mart. }\end{array}$ & ipê-mirim & Native & 0,5 \\
\hline & $\begin{array}{l}\text { Handroanthus albus (Cham.) } \\
\text { Mattos }\end{array}$ & ipê-amarelo & Native & 4,3 \\
\hline & Handroanthus & & & \\
\hline & $\begin{array}{c}\text { chrysotrichus (Mart. ex A.DC.) } \\
\text { Mattos }\end{array}$ & ipê-amarelo & Native & 0,5 \\
\hline \multirow[t]{5}{*}{ Bignoniaceae } & $\begin{array}{c}\text { Handroanthus } \\
\text { heptaphyllus (Vell.) Mattos }\end{array}$ & ipê-roxo & Native & 1,0 \\
\hline & $\begin{array}{l}\text { Handroanthus impetiginosus } \\
\text { (Mart. ex DC.) Mattos }\end{array}$ & ipê-roxo & Native & 1,9 \\
\hline & Jacaranda mimosifolia D. Don & jacarandá-mimoso & Exotic & 0,5 \\
\hline & $\begin{array}{c}\text { Tabebuia impetiginosa (Mart. ex } \\
\text { DC.) }\end{array}$ & ipê-roxo & Native & 0,5 \\
\hline & Tecoma stans (L.) Juss ex. Kenth & ipê-mirim & Exotic & 1,9 \\
\hline Biraginaceae & Cordia ecalyculata Vell. & café-de-bugre & Native & 0,5 \\
\hline Cactaceae & $\begin{array}{c}\text { Nopalea cochenillifera (L.) Salm- } \\
\text { Dyck }\end{array}$ & cacto & Exotic & 0,5 \\
\hline Convolvulaceae & Ipomoea quamoclit L. & primavera & Native & 1,0 \\
\hline \multirow[t]{2}{*}{ Cupressaceae } & Cupressus sempervirens L. & cipreste & Exotic & 1,0 \\
\hline & Codiaeum variegatum L. & crotón & Exotic & 1,0 \\
\hline \multirow[t]{4}{*}{ Euphorbiaceae } & $\begin{array}{l}\text { Euphorbia pulcherrima Wild. Ex } \\
\text { Klotzsch. }\end{array}$ & flor-de-páscoa & Exotic & 0,5 \\
\hline & Ficus variegata $\mathrm{L}$. & ficus, figueira & Exotic & 1,4 \\
\hline & Bauhinia variegata $\mathrm{L}$. & pata-de-vaca & Exotic & 17,5 \\
\hline & $\begin{array}{c}\text { Caesalpinia pluviosa var. peltop } \\
\text { horoides (Benth.) G.P.Lewis }\end{array}$ & sibipiruna & Native & 1,0 \\
\hline Fabaceae & Cassia fistula $\mathrm{L}$ & cássia-imperial & Exotic & 1,0 \\
\hline \multirow[t]{3}{*}{ Caesalpinioideae } & Hymenaea courbaril L. & jatobá & Native & 0,5 \\
\hline & Machaerium villosum Vogel & jacarandá-mineiro & Native & 0,5 \\
\hline & $\begin{array}{c}\text { Schizolobium parahyba (Vell) S. } \\
\text { F. Blake. }\end{array}$ & guapuruvu & Native & 0,5 \\
\hline Fabaceae Faboideae & Poecilanthe parviflora Benth. & coração-de-negro & Native & 0,5 \\
\hline
\end{tabular}




\begin{tabular}{|c|c|c|c|c|}
\hline Fabaceae Mimosoideae & $\begin{array}{c}\text { Leucaena leucocephala (Lam.) } \\
\text { de Wit }\end{array}$ & leucena & $\begin{array}{l}\text { Exotic- } \\
\text { Invader }\end{array}$ & 0,5 \\
\hline Lauraceae & Persea americana Mill. & abacateiro & Exotic & 2,4 \\
\hline Lythraceae & Lagerstroemia indica L. & resedá & Exotic & 1,4 \\
\hline Malvaceae & Hibiscus rosa-sinensis L. & hibisco & Exotic & 2,8 \\
\hline \multirow{2}{*}{ Melastomataceae } & $\begin{array}{l}\text { Tibouchina granulosa (Desr.) } \\
\text { Cogn. }\end{array}$ & quaresmeira & Native & 1,9 \\
\hline & $\begin{array}{l}\text { Tibouchina mutabilis (Vell.) } \\
\text { Cogn. }\end{array}$ & manacá-da-serra & Native & 0,5 \\
\hline \multirow{4}{*}{ Moraceae } & Artocarpus heterophyllus Lam. & jaqueira & Exotic & 1,0 \\
\hline & Morus nigra L. & amora-negra & Exotic & 3,8 \\
\hline & Eugenia involucrata DC. & pitanga-preta & Native & 3,3 \\
\hline & $\begin{array}{l}\text { Eugenia uniflora L. } \\
\text { Pimenta }\end{array}$ & pitangueira & Native & 2,4 \\
\hline \multirow[t]{3}{*}{ Myrtaceae } & $\begin{array}{c}\text { pseudocaryophyllus (Gomes) } \\
\text { Landrum }\end{array}$ & cravo-do-mato & Native & 0,5 \\
\hline & Psidium cattleianum Sabine & araçá-amarelo & Native & 0,5 \\
\hline & Psidium guajava L. & goiabeira & $\begin{array}{l}\text { Naturalize } \\
\quad \mathrm{d}\end{array}$ & 3,8 \\
\hline Pandanaceae & Pandanus sp. & pândano & Exotic & 3,3 \\
\hline Pittosporaceae & Pittosporum undulatum Vent. & pitósporo-ondulado & $\begin{array}{l}\text { Exotic- } \\
\text { Invader }\end{array}$ & 0,5 \\
\hline Poaceae & Saccharum officinarum L. & cana-de-açúcar & Cultivated & 4,3 \\
\hline Punicaceae & Punica granatum L. & romanzeira & Exotic & 0,5 \\
\hline Rosaceae & $\begin{array}{c}\text { Eriobotrya japonica (Thunb.) } \\
\text { Lindl. }\end{array}$ & ameixa-amarela & Exotic & 1,9 \\
\hline \multirow{3}{*}{ Rutaceae } & Citrus sp. & limoeiro & Exotic & 1,4 \\
\hline & Murraya paniculata (L.) Jack & murta & Exotic & 1,4 \\
\hline & Brunfelsia uniflora (Pohl) D.Don & manacá-de-cheiro & Native & 1,0 \\
\hline \multirow[t]{2}{*}{ Solanaceae } & Solanum lycocarpum A.St.-Hil. & lobeira & Native & 0,5 \\
\hline & Solanum mauritianum Scop. & fumo-bravo & Native & 0,5 \\
\hline Verbenaceae & Duranta repens L. & pingo-de-ouro & Native & 0,5 \\
\hline 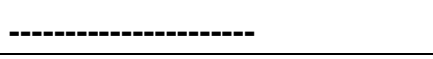 & 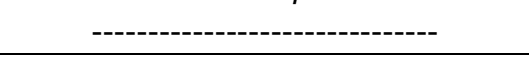 & indeterminate & -------------- & 7,6 \\
\hline
\end{tabular}

Source: the own authors

The strong presence of the Fabaceae Caesalpinioideae family is due to, mostly, to the big quantity of Bauhinia variegata trees. Still, $10,9 \%$ of trees belonging to the Bignoniaceae family (Figure 5). Most part of the representants found here are natives and commonly known as "ipês". Besides a floration welfare they provide, the ipês can be planted in parks and squares or even in sidewalks (CEMIG, 2011). 
Figure 5 - Rate in percentage of found families in the afforestation of streets in Véu das Noivas neighborhood, Poços de Caldas/MG

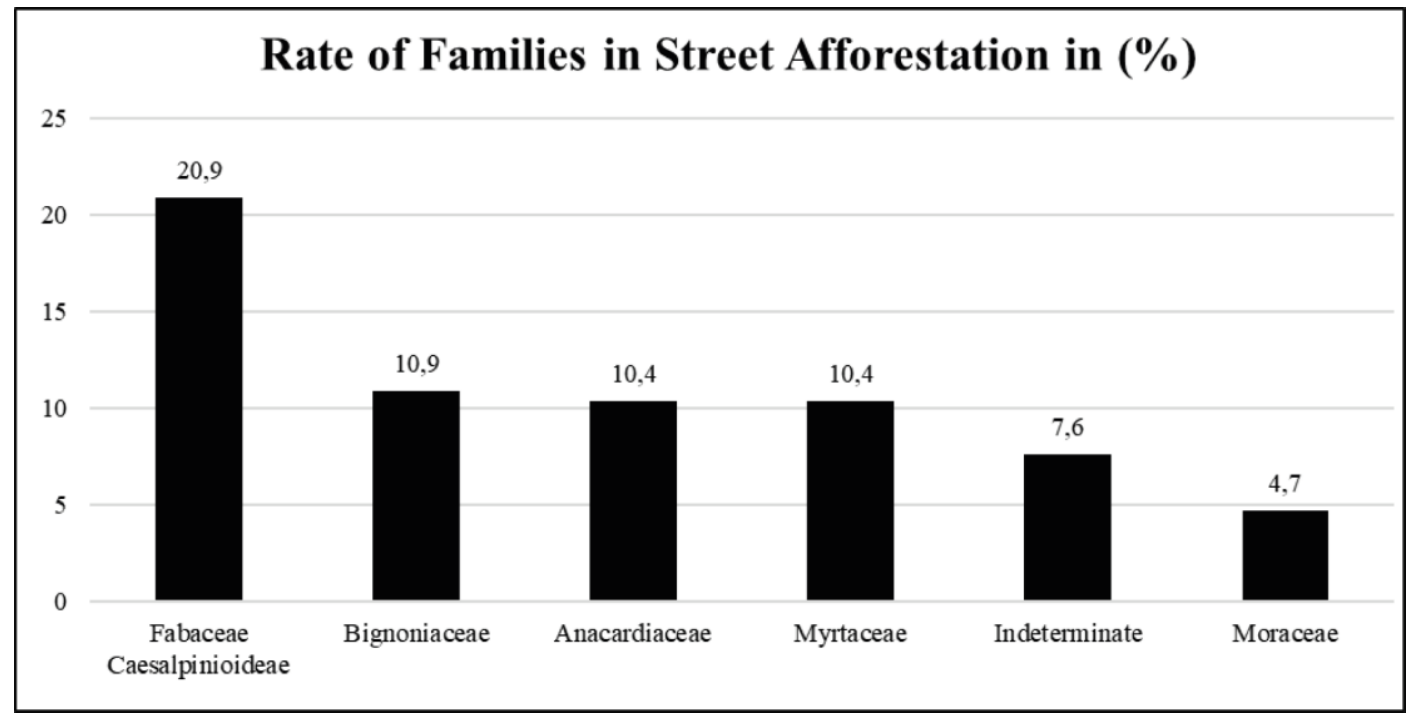

Source: the own authors

According to Kramer and Krupek (2012), the usage of native species in the urban afforestation brings the cultural identity of the region. It was observed, however, the predominace of exotic species present in the afforestation of streets, existing 54,5\% of exemplars. The naturalized species are constituted only by Psidium guajava trees (3,8\%) and those cultivated by Saccharum officinarum (4,3\%) (Figure 6).

Figure 6 - Origin of the trees planted in the streets in Véu das Noivas, Poços de Caldas/MG

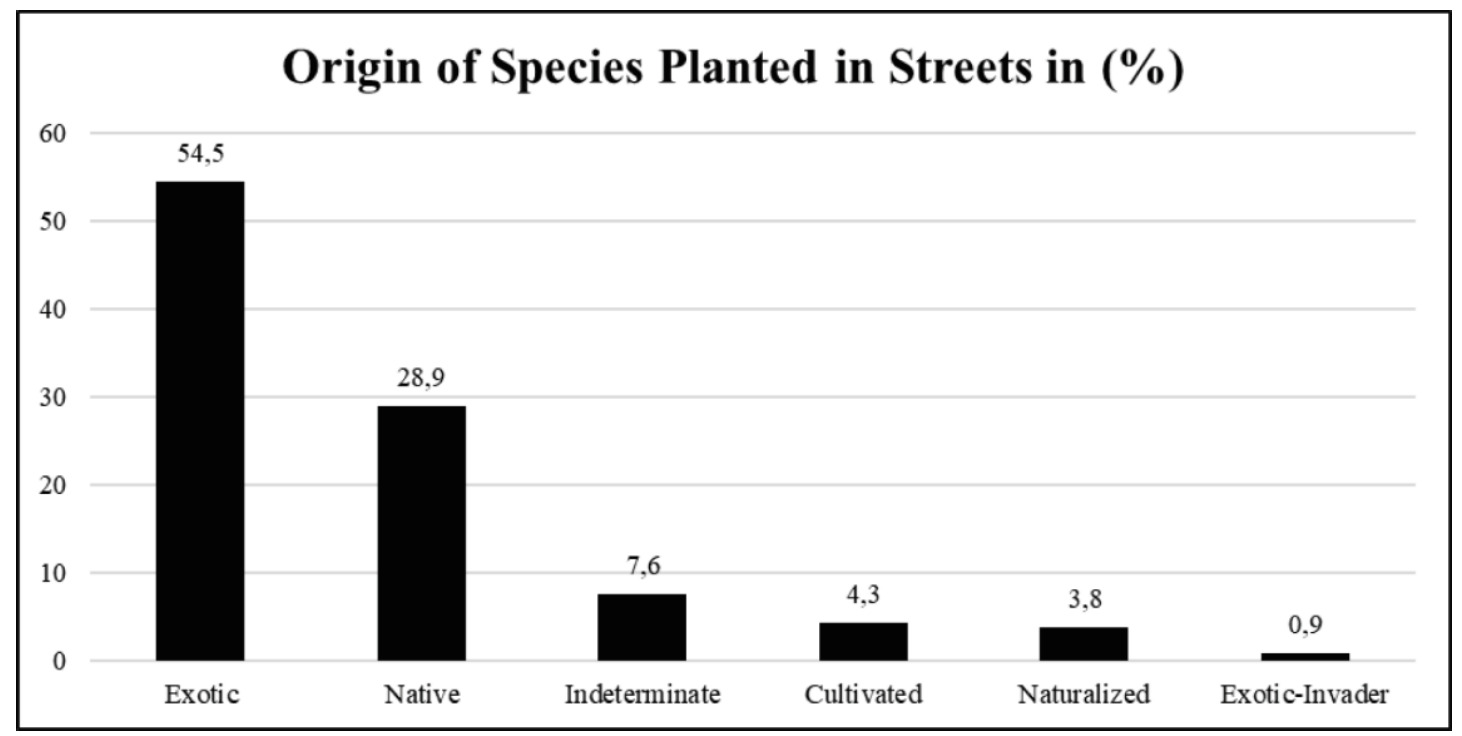

Source: the own authors 


\subsection{Green Spaces Afforestation}

It was observed the existence of some green spaces at the entrance of the neighborhood, being well distributed and contributing to the thermal comfort sensation of the local. In this way, it was also observed the existence of 185 trees in these areas, in a total of 44 species. In spite of the variability of existing species, 14 of them own less than $1 \%$ of exemplars (Table 4 ).

Many trees of the species Cupressus sempervirens L. were accounted and located, mainly, at the entrance of the neighborhood. Among the found exemplars, $13,5 \%$ of them are from this species, going over the maximum value of rate for individuals of a same species, 10\% (CEMIG, 2011) (Table 4). As it can be observed in this project, trees of this species were used for vertical landscaping and also for street afforestation.

Due to the time of the year in which data were collected, many trees were without leaves and it contributed to many of them, despite the fact that they had their geographic coordinates gathered, to be not identified (10,8\%) (Table 4).

It was also noticed the existence of some fruit trees species, such as Citrus sp., Eugenia uniflora, Morus nigra, Persea americana and Psidium guajava. It's useful to emphasize that some exemplars of Psidium guajava were located in ravines and presented iminent risks of falling. Besides focusing on those trees which may fall, it's necessary to point out possible accidents caused by fruits of the Persea americana species.

Table 4 - Family, scientific name, common name, origin and rate $(F)$ in percentage of the found species in the afforestation of green spaces in Véu das Noivas neighborhood, Poços de Caldas/MG

\begin{tabular}{|c|c|c|c|c|}
\hline Family & Scientific Name & Common Name & Origin & F \% \\
\hline Anacardiaceae & Schinus terebinthifolia Raddi & $\begin{array}{c}\text { aroeira- } \\
\text { pimenteira }\end{array}$ & Native & 1,1 \\
\hline Araucariaceae & $\begin{array}{c}\text { Araucaria angustifolia (Bertol.) } \\
\text { Kuntze }\end{array}$ & araucária & Native & 2,2 \\
\hline Arecaceae & $\begin{array}{c}\text { Dipsis lutescens (H.Wendl.) Beentje \& } \\
\text { J.Dransf. }\end{array}$ & areca-bambu & Exotic & 0,5 \\
\hline
\end{tabular}




\section{Bignoniaceae}

\section{Cactaceae \\ Convolvulaceae Cupressaceae Cycadaceae Euphorbiaceae}

\section{Fabaceae Caesalpinioideae}

\section{Fabaceae Mimosoideae}

\section{Lamiaceae \\ Lauraceae \\ Malvaceae \\ Melastomataceae}

Moraceae

\section{Myrtaceae}

Oleaceae

Pandanaceae

Pinaceae

Pittosporaceae

Platanaceae

Poaceae

Proteaceae

Rutaceae

\section{Livistona chinensis (N. J. Jacquin) R. Brown ex Mart. Syagrus romanzoffiana (Cham.) Glassman} Handroanthus albus (Cham.) Mattos Handroanthus chrysotrichus (Mart. ex A.DC.) Mattos

Handroanthus impetiginosus (Mart. ex DC.) Mattos

$$
\begin{aligned}
& \text { Jacaranda mimosifolia D. Don } \\
& \text { Tabebuia heptaphylla (Vellozo) } \\
& \text { Toledo } \\
& \text { Cactus sp. } \\
& \text { Opuntia ficus-indica Mill } \\
& \text { Ipomoea quamoclit L. } \\
& \text { Cupressus sempervirens L. } \\
& \text { Cycas circinalis L. } \\
& \text { Ficus variegata L. }
\end{aligned}
$$
Bauhinia variegata $\mathrm{L}$.

Caesalpinia pluviosa var. peltophoroid es (Benth.) G.P.Lewis

Hymenaea courbaril L.

$$
\begin{gathered}
\text { Machaerium villosum Vogel } \\
\text { Pterogyne nitens Tul. } \\
\text { Inga sessilis (Vell.) Mart. }
\end{gathered}
$$

Leucaena leucocephala (Lam.) de Wit

$$
\text { Piptadenia gonoacantha (Mart.) }
$$

$$
\text { J.F.Macbr. }
$$

Plectranthus barbatus Andr. Persea americana Mill. Ceiba speciosa (A. St.-Hil.) Ravenna Tibouchina granulosa (Desr.) Cogn. Ficus elastica var. robusta Roxb. ex Hornem Morus nigra L. Eucalyptus sp.

Eugenia uniflora L.

Psidium guajava $\mathrm{L}$. Ligustrum lucidum W. T. Aiton Pandanus sp. Pinus sp.

Pittosporum undulatum Vent. Platanus sp.

Saccharum officinarum $L$. Grevillea robusta A.M.Cunn. ex R. Br. Citrus sp.

Zanthoxylum rhoifolium Lam. palmeira-de-

leque-da-china

Exotic

jarobá
ipê-amarelo
ipê-amarelo
ipê-roxo-bola
jacarandá-
mimoso
pê-argentino ou
ipê-rosa
cactos
figo-da-índia
primavera
cipreste

palmeira-sagu

ficus, figueira

pata-de-vaca

sibipiruna

jatobá

jacarandá-do-

campo

amendoim-bravo ingá

leucena

$$
\begin{gathered}
\text { pau-jacaré } \\
\text { boldo }
\end{gathered}
$$

abacateiro

paineira

quaresmeira

fícus

amora-negra

eucalipto

pitangueira

goiabeira

alfenheiro

pândano

pinus

pitósporo-

ondulado

plátano

cana-de-açúcar

grevilha

limoeiro

mamica-decadela
Native $\quad 1,6$

Native $\quad 1,1$

Native $\quad 1,1$

Native $\quad 2,2$

Exotic $\quad 1,6$

Exotic $\quad 1,1$

Exotic $\quad 0,5$

Exotic $\quad 0,5$

Native $\quad 0,5$

Exotic $\quad 13,5$

Exotic $\quad 1,1$

Exotic $\quad 0,5$

Exotic $\quad 2,7$

Native $\quad 8,1$

Native $\quad 0,5$

Exotic $\quad 2,7$

Native $\quad 3,2$

Native $\quad 2,7$

Invader

Exotic $\quad 0,5$

Exotic $\quad 0,5$

Native $\quad 0,5$

Native $\quad 1,1$

Exotic $\quad 1,1$

Exotic $\quad 2,2$

Exotic $\quad 1,1$

Native $\quad 1,6$

Naturalized $\quad 6,5$

Exotic $\quad 1,1$

Exotic $\quad 5,4$

Exotic $\quad 1,1$

Exotic-

Invader 8,1

Exotic $\quad 0,5$

Cultivated $\quad 1,1$

Exotic $\quad 1,1$

Exotic $\quad 1,1$

Native $\quad 0,5$

Exotic- $\quad 0,5$ 


\begin{tabular}{lcccc}
\hline Sapindaceae & Matayba guianensis Aubl. & camboatá- & Native & 0,5 \\
Solanaceae & Solanum mauritianum Scop. & $\begin{array}{c}\text { fumo-bravo } \\
\text { indeterminate }\end{array}$ & Native & 1,1 \\
-------- & 10,8 \\
\hline
\end{tabular}

Source: the own authors

The high rate of Fabaceae Ceasalpinioideae and Cupressaceae families (Figure 7) is due mainly to the found trees of the Caesalpinia pluviosavar. peltophoroides and Cupressus sempervirens species, respectively. Even though, it's still worrisome the quantity of trees which belong to the Pittosporaceae family, once they are considered invaders.

Figure 7 - Rate in percentage of found families in the afforestation of green spaces in Véu das Noivas neighborhood, Poços de Caldas/MG

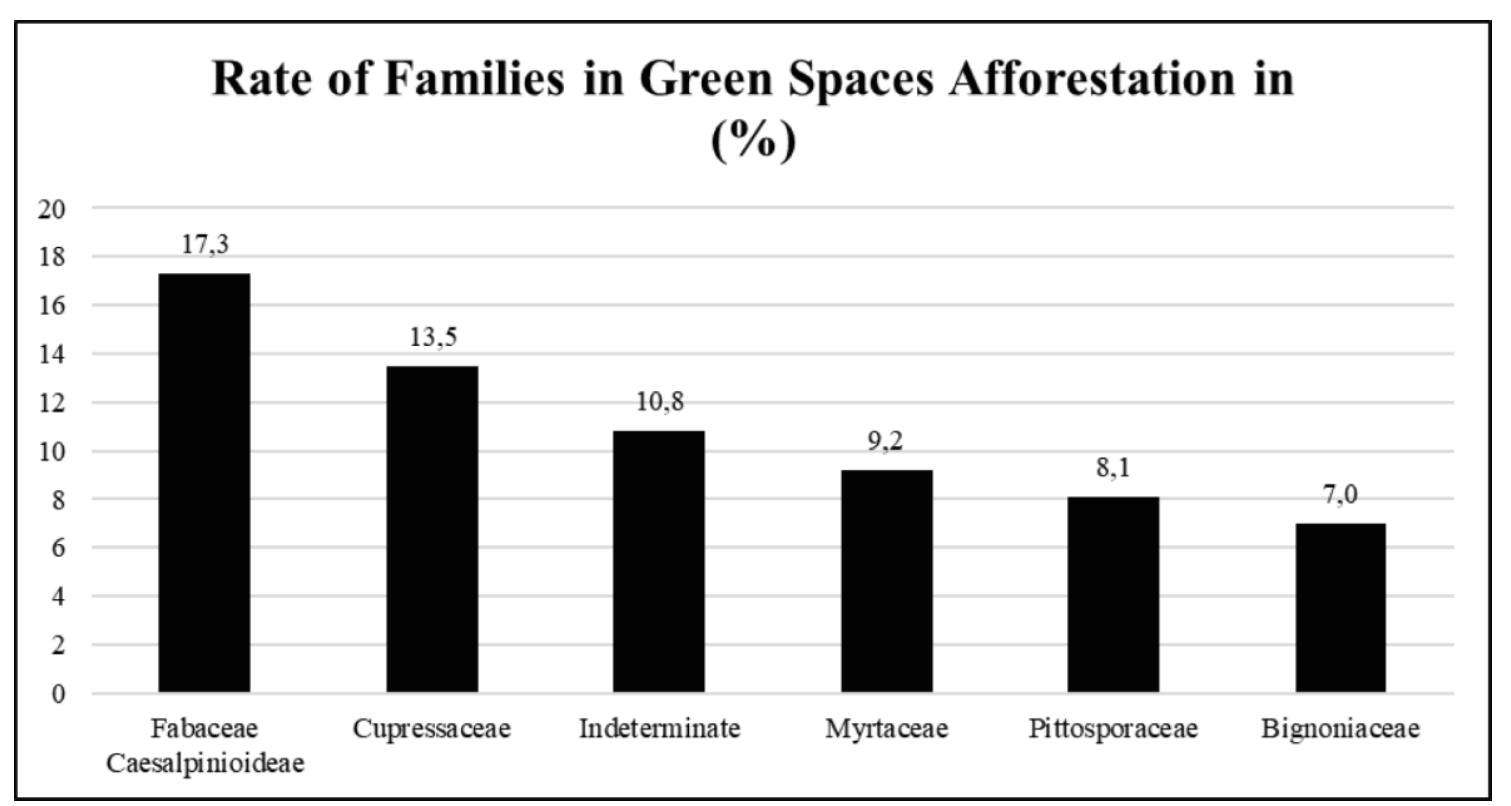

Source: the own authors

In the green spaces, it was observed a higher rate of exotic species $(42,7 \%)$ if compared to the natives $(30,3 \%)$, existing, moreover, $8,7 \%$ of trees of an exoticinvader origin (represented by the Leucaena leucocephala and Pittosporum undulatum species) (Figure 8). This found one is in agreement with Freitas et al. (2015). 
Figure 8 - Origin of the planted trees in green spaces in Véu das Noivas neighborhood, Poços de Caldas/MG

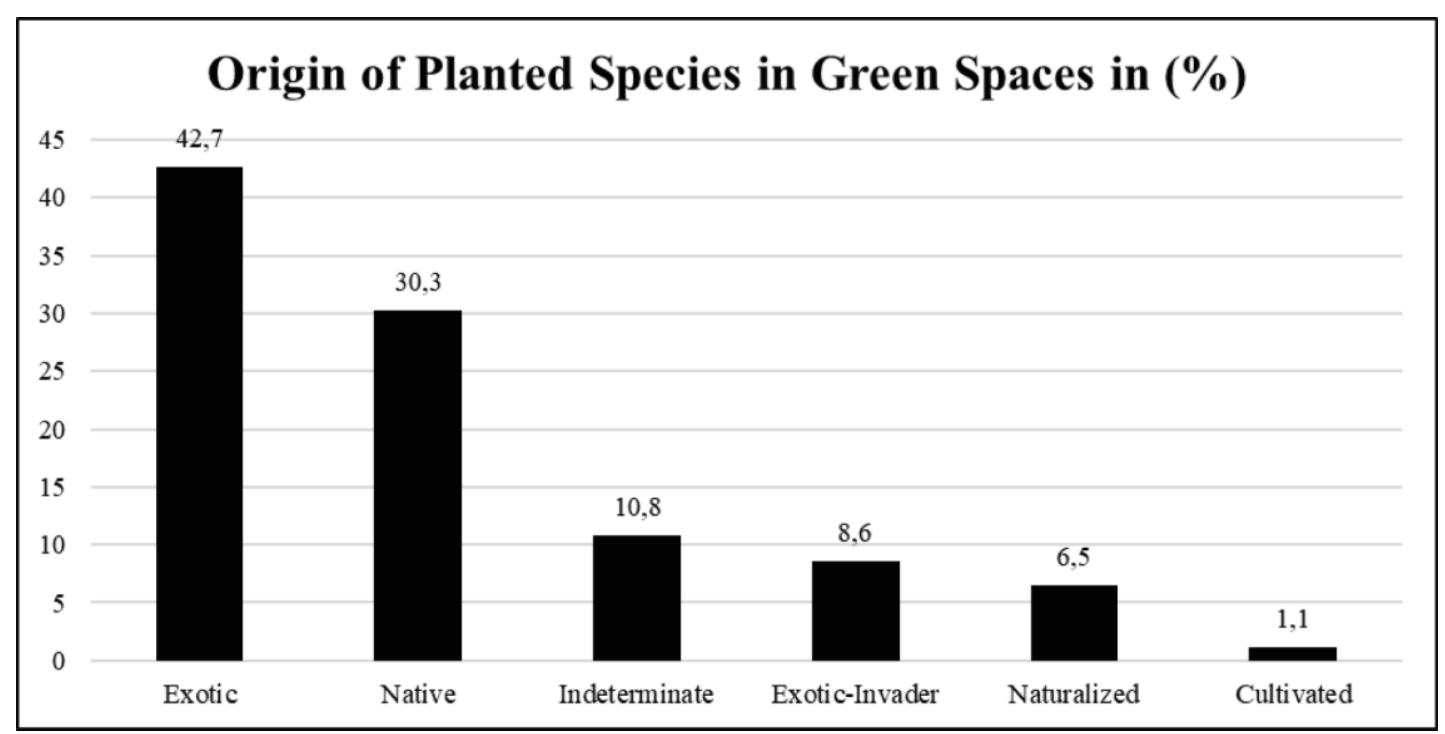

Source: the own authors

\subsection{Mapping}

Geotechnology tools are able to enhance the management of green areas and land use and occupation (SAITO et al., 2016), causing improvements in the maintenance and monitoring of these trees and a consequent reduction in public expenses. In this way, according to the gathered coordinates, necessary data was gathered to create maps by geoprocessing softwares, such as ArcGis ${ }^{\circledR}$ (Figures 9 and 10). 
Figure 9 - Most occuring species present in Véu das Noivas neighborhood, Poços de Caldas/MG

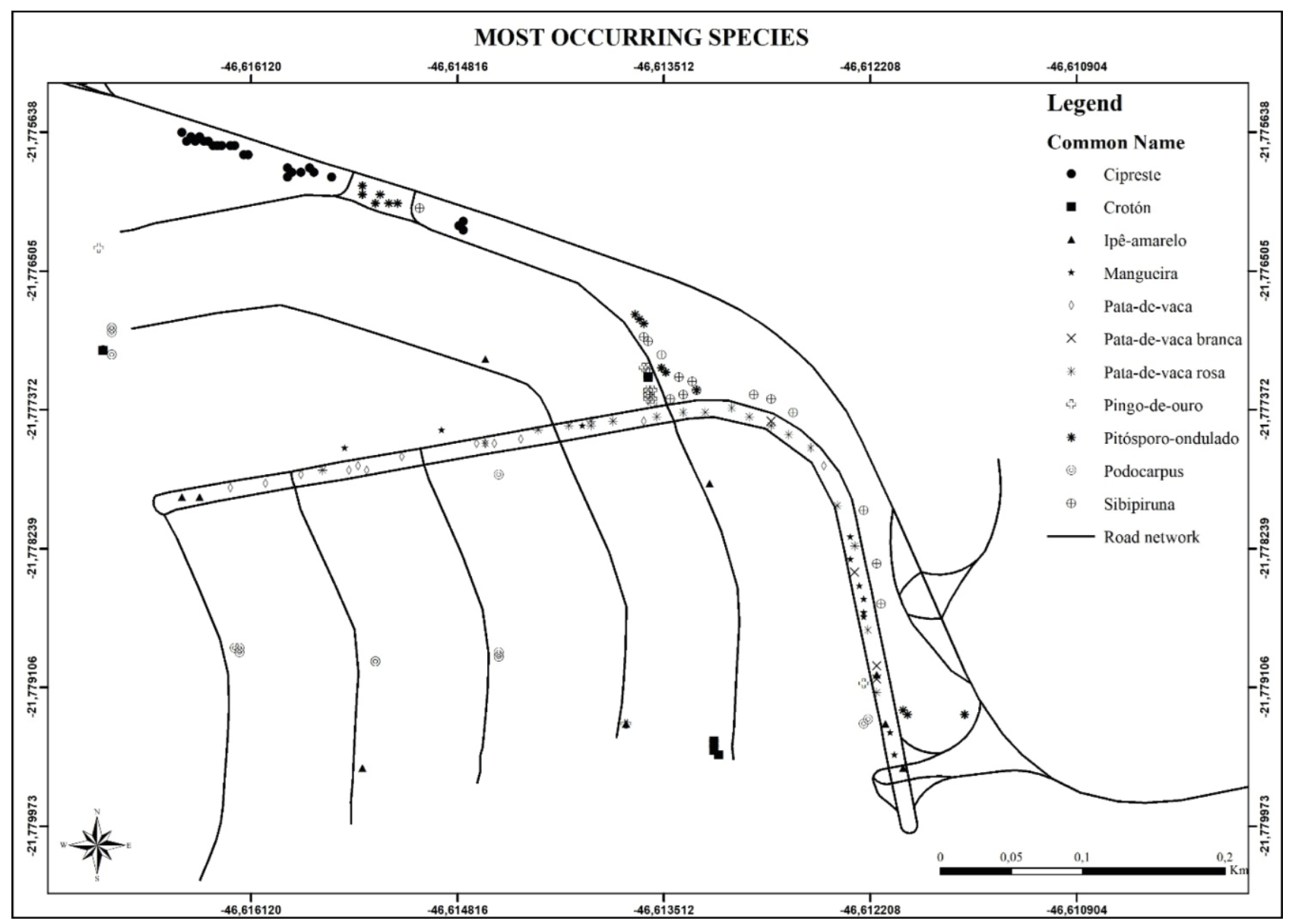

Source: the own authors. 
Figure 10 - Location and origin of trees present in Véu das Noivas neighborhood, Poços de Caldas/MG

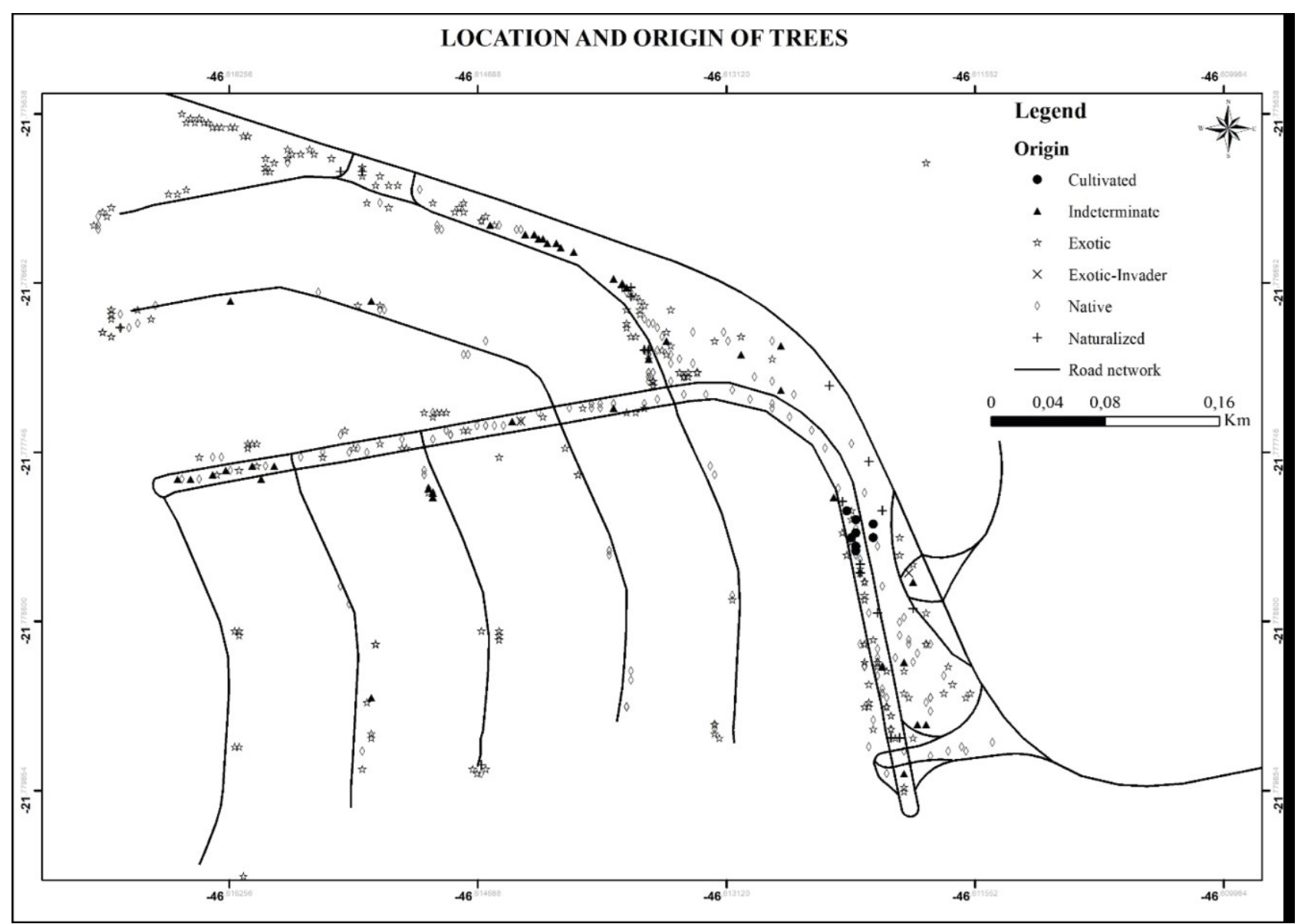

Source: the own authors.

Through the Tableed maps visualizations, it was verified the rate of afforestation in the studied neighborhood, being also observed an increase of trees located in the central flowerbed of João Ferrari Avenue and in a green space located at the entrance of the neighborhood. There were found, still, trees in the same location, what contributed for the coordinates to be gathered and, consequently with it, to cause a distortion of the visualization of these spots in the Tableed maps, once there's an overlap. 


\section{CONCLUSION}

Through the gathering of data, it was possible to verify the prevalence of exotic species if compared to the native ones. It generates a serious problem due to the lack of cultural identification with population and it's local environment, just like the loss of the biodiversity of the urban environment. It's expected with it that our project may contribute for providing information about the adequate usage of species and contribute to a more efficient planning of the urban afforestation of Poços de Caldas/MG.

It's suggested that the gathered data are properly cataloged and disponible for the population, in order to contribute for the education and environmental awareness about the benefits of the proper urban afforestation. Generate a database of the trees of the city may contribute to the construction of a better and efficient city management.

\section{ACKNOWLEDGMENT}

To the Foundation of Support for Researching of Minas Gerais - FAPEMIG, for the concession of the scholarship of scientific research to the first author.

\section{REFERENCES}

AMATO-LOURENÇO, L. F.; MOREIRA, T. C. L.; ARANTES, B. L. de; SILVA FILHO, D. F. da; MAUAD, T. Metrópoles, cobertura vegetal, áreas verdes e saúde. Estudos Avançados, São Paulo. 2016; 30(86):113-130. Available at: http://www.scielo.br/pdf/ea/v30n86/0103-4014-ea-30-86-00113.pdf. Acessed in: 18 May 2019.

BARBOSA, M. C.; FONTES, M. S. G. de C. Jardins verticais: modelos e técnicas. Parc Pesquisa em Arquitetura e Construção. 2016; 7(2): 114-124. Universidade Estadual de Campinas. Available at:

https://periodicos.sbu.unicamp.br/ojs/index.php/parc/article/view/8646304/14825. Acessed in: 12 May 2018. 
BUCKERIDGE, M. Árvores urbanas em São Paulo: planejamento, economia e água. Estudos Avançados. 2015; 29(84): 85-101. Available at: http://www.scielo.br/scielo.php?script=sci_arttext\&pid=S010340142015000200085\&Ing=en\&nrm=iso. Acessed in: 28 Jun. 2019.

CEMIG. COMPANHIA ENERGÉTICA DE MINAS GERAIS. Manual de Arborização. 2011. Available at:

http://www.cemig.com.br/sites/imprensa/ptbr/Documents/Manual_Arborizacao_Cemi g_Biodiversitas.pdf. Acessed in: 29 Oct. 2017.

DADVAND, P.; BARTOLL, X.; BASAGAÑA, X.; DALMAU-BUENO, A.; MARTINEZ, D.; AMBROS, A.; CIRACH, M.; TRIGUERO-MAS, M.; GASCON, M.; BORRELL, C.; NIEUWENHUIJSEN, M. J. Green spaces and General Health: Roles of mental health status, social support, and physical activity. Environment International, 2016; 91: 161167. Disponível em: https://www.sciencedirect.com/science/article/pii/S0160412016300666. Acesso em: 18 May 2019.

FLORA DO BRASIL ONLINE. FBO. Flora do Brasil 2020 em construção. Jardim Botânico do Rio de Janeiro. Available at: http://floradobrasil.jbrj.gov.br. Acessed in: 16 May 2018.

FREITAS, W. K. de; PINHEIRO, M. A. S.; ABRAHÃO, L. L. F. Análise da Arborização de Quatro Praças no Bairro da Tijuca, RJ, Brasil. Floresta e Ambiente; 2015; 22(1): 23-31. Available at: http://www.scielo.br/scielo.php?script=sci_arttext\&pid=S2179$80872015000100023 \&$ Ing=pt\&tlng=pt. Acessed in: 29 Jun. 2019.

GOZALO, G. R.; MORILLAS, J. M. B.; GONZÁLEZ, D. M.; MORAGA, P. A. Relationships among satisfaction, noise perception, and use of urban green spaces. Science Of The Total Environment. 2018; 624: 438-450. Available at: https://www.sciencedirect.com/science/article/pii/S004896971733574X\#f0005. Acessed in: 18 May 2019.

KRAMER, J. A.; KRUPEK, R. A. Caracterização florística e ecológica da arborização de praças públicas do município de Guarapuava, PR. Revista Árvore. 2012; 36(4): 647658. Available at: http://www.scielo.br/scielo.php?script=sci_arttext\&pid=S010067622012000400007\&lng=en\&nrm=iso\&tlng=pt. Acessed in: 28 Jun. 2019.

MARICATO, E.; COLOSSO, P.; COMARÚ, F. de A. Um projeto para as cidades brasileiras e o lugar da saúde pública. Saúde em Debate. 2018; 42(3): 199-211. Available at: http://www.scielo.br/scielo.php?script=sci_arttext\&pid=S0103$11042018000700199 \&$ lang=pt. Acessed in: 29 Jun. 2019.

PREFEITURA MUNICIPAL DE POÇOS DE CALDAS. PMPC. Revisão do plano diretor do munícipio de Poços de Caldas. Poços de Caldas: Prefeitura de Poços de Caldas, 2006. 
SAITO, N. S.; ARGUELLO, F. V. P.; MOREIRA, M. A.; SANTOS, A. R. dos; EUGENIO, F. C.; FIGUEIREDO, A. C. Uso da geotecnologia para análise temporal da cobertura florestal. Cerne. 2016; 22(1): 11-18. Available at:

http://www.scielo.br/scielo.php?script=sci_arttext\&pid=S0104$77602016000100011 \&$ lang=pt. Acessed in: 29 Jun. 2019.

SILVA, L. L. H. da; OLIVEIRA, E.; CALEGARI, L.; PIMENTA, M. C.; DANTAS, M. K. L. Características Dendrométricas, Físicas e Químicas da Myracrodruon urundeuva e da Leucaena leucocephala. Floresta e Ambiente. 2017; 24: 1-8. Available at: http://www.scielo.br/scielo.php?script=sci_arttext\&pid=S2179$80872017000100134 \&$ lang=pt. Acessed in: 28 Jun. 2019.

THE PLANT LIST (2018). Version 1. Available at: http://www.theplantlist.org/. Acessed in: 16 May 2018. 